\title{
For Independent Poland and the Emancipation of the Working Class
}

\author{
The Poles in the IWMA, 1864-1876
}

Krzysztof Marchlewicz

The Polish question left a clear mark in the formation of the International Working Men's Association (IWMA). If the previous stages of the development of the European labour movement were the activities of the Fraternal Democrats in the 1840s, then the foundation of the International Committee (1855), from which in turn the International Association (1855-59) had stemmed, it is difficult not to notice the presence of many Polish emigrants in their ranks. All of these organisations quite frequently engaged themselves in the pro-Polish manifestations in the countries of Western Europe, and the press associated with them widely informed about the situation in Poland. The leaders of these bodies, George Julian Harney, Ernest Jones, Karl Schapper or Felix Pyat, often expressed their support for the idea of Polish independence. ${ }^{1}$

\section{The IWMA and the Polish Question}

The Polish matters accompanied the very beginnings of the First International. Although opinions of some historians, who stated that the Association was established during the London manifestation in support of the January Uprising in 1863 , were incorrect, ${ }^{2}$ it is a fact that bloody events in Poland gave a new impulse to the contacts between the workers from Paris and London, initiated in the early 1860 s. This impulse was a desire to articulate solidarity with the Poles who struggled against the tsarist regime. In July 1863 Henri Tolain, Auguste Bibal, Joseph-Étienne Perrachon, Jean Aubert, Antoine Cohadon and AndréPierre Murat arrived in London and participated in a pro-Polish demonstration

1 Peter Brock, "Polish Democrats and English Radicals 1832-1862. A Chapter in History of Anglo-Polish Relations", Journal of Modern History, 25/2, (1953), pp. 139-156; Henry Weisser, British working class movements and Europe 1815-1848 (Manchester, 1975), pp. 118-192.

2 Peter Brock, Z dziejów Wielkiej Emigracji w Anglii (Warszawa, 1958), p. 36; Celina Bobińska, Marks i Engels a sprawy polskie do lat osiemdziesiatych XIX wieku (Warszawa, 1954), p. 194.

(C) KRZYSZTOF MARCHLEWICZ, 2018 | DOI 10.1163/9789004335462_012

This is an open access chapter distributed under the terms of the prevailing CC-BY-NC License. 
in St. James's Hall. On the following day (23 July 1863), they met the British Trades Union members once again. As a result of these talks, a decision regarding a close intentional cooperation among workers was made. ${ }^{3}$ It is a relatively unknown fact that Prince Władysław Czartoryski, a leader of the conservative wing of the Polish emigration, participated in the costs of the journey of the French delegates to London, offering them $45^{\circ}$ francs. Władysław Czartoryski son of better-known the late Prince Adam Jerzy Czartoryski - was not, of course, a willing supporter of the international labour movement. His intention was to establish a broad front of public opinion and political bodies which could influence the governments of England and France regarding the Polish question. ${ }^{4}$ In this way, however, Czartoryski modestly contributed to the success of AngloFrench talks in 1863, which ultimately led to the establishment of the IWMA fourteen months later, in September 1864.

The words of George Lichtheim may be repeated here, stating that the IWMA was "an attempt on the part of British and French labour leaders to find a common language: at first in defence of Poland, then over the widening range of political and industrial topics". ${ }^{5}$ In spite of this, the Poles and the Polish cause although not insignificant - had never played a really important role in the First International. Their presence and influence were especially visible in two dimensions. During the 186os, the members of the Central (later on: General) Council of the IWMA willingly participated in the celebrations commemorating anniversaries of the Polish national uprisings, and gave publicity to the problems encountered by the Poles deprived of their own statehood. The Association helped to organise the pro-Polish meeting in St. Martin's Hall in London in March 1865, during which Peter Fox, John Nieass, Victor Le Lubez and Johann G. Eccarius were active participants. In January 1866, a similar demonstration was attended by Karl Marx, William R. Cremer, P. Fox and V. Le Lubez. During a mass meeting on 22 January 1867 , assembled in commemoration of the fourth anniversary of the January Uprising in London Cambridge Hall, Hermann Jung, Alexandre Besson, K. Marx and J.G. Eccarius also voiced their opinions. In the reports of these meetings the prominent role of the IWMA as the co-organiser was always emphasised, with its representatives expressing

3 See The Bee-Hive, 25 July 1863, no. 93, pp. 4-6; cf. George Lichtheim, A Short History of Socialism (London, 1980), p. 171.

4 Stefan Kieniewicz, Powstanie styczniowe (Warszawa, 1972), p. 593; cf. Irena Koberdowa, Pierwsza Międzynarodówka 1864-1876. Sukcesy i porażki (Warszawa, 1987), pp. 42-43.

5 Lichtheim, A Short History, p. 182. 
their solidarity with the calls to reinstate a free Poland. Moreover, even when the Central Council was not directly engaged in such undertakings, its Polish members were empowered to represent the Association. ${ }^{6}$

In the inner discussions of the IWMA leaders, however, the Polish cause played quite a different role. It became a subject of a fierce confrontation between the supporters of active participation in national and international undertakings and those who believed that the First International should focus on social and economical issues. On one side of this conflict were Karl Marx and some of the British trade unionists. In the 1860s and 1870s, Marx popularised the thesis that the international labour movement could not remain indifferent in relation to the Polish aspirations for independence. He accepted the opinion of the Polish social-democrats that an oppressed nation has to first direct its energy towards abolishing the oppression, and only after this it would be able to concentrate on internal transformation. In one of his letters to Karl Kautsky, Marx stated that the Poles - similarly to the Irish - have the right, or even an obligation, "to be national before they become international". ${ }^{7}$ According to Marx, the alliance of Russia, Austria and Prussia - which was cemented by the partitions of Poland - was now the keystone of the old order in Europe. As a result, any support given to the Polish struggle for freedom was simultaneously in favour of the European revolution. Marx underlined also the progressive nature of some Polish revolutionary manifestos (especially from 1846), and he was undoubtedly one of the most sympathetic among the members of the IWMA towards the Poles. ${ }^{8}$

However, there was strong opposition towards the idea that the Association should always and unreservedly voice the Polish cause. It came mostly from the continental sections of the IWMA. Many French, Belgian and Swiss activists were under the influence of Pierre-Joseph Proudhon, and like himself, they were critical to the institution of a state. They expressed, first of all, the necessity to improve the situation of the working class through the establishment of cooperatives and provision of convenient credits. The Proudhonians distanced themselves even from strikes and any engagement in political struggle, to include the fight for Polish independence. They also knew the work of Proudhon, Si les traités de 1815 ont cessé d'exister. Actes du futur congrès (1863),

6 Irena Koberdowa, Pierwsza Międzynarodówka i lewica Wielkiej Emigracji (Warszawa, 1964), pp. 141-171.

7 Marx to Kautsky, 7 Feb. 1882, in Helena Michnik (ed), Marks i Engels o Polsce (Warszawa, 1960), II, p. 122.

8 Adam Ciołkosz, Karol Marks a powstanie styczniowe (London, 1963), pp. 14-38. 
where he strongly opposed the reconstruction of independent Poland, and stated that the partitions of Poland, which already gained its legal validity, were a historical necessity, serving a useful purpose for European progress. With such theoretical background, it was hard to expect that Proudhon's followers would be enthusiastically supporting the IWMA engagement in the Polish cause. ${ }^{9}$

A relatively quick struggle within the First International between these two conflicting parties took place. In September 1865, during a conference in London - when the programme for the next congress of the Association was forming - Victor Le Lubez, Pierre Vésinier, César De Paepe and John Weston voiced a number of objections regarding the Polish point of the congress agenda, which was proposed by the General Council. They opposed such explicit distinction of this problem, and tried to convince their comrades that the IWMA should, above all, focus on social issues. In their opinion, as far as the discussion on national liberation was considered, it shouldn't be limited to Poland but have a universal character. ${ }^{10}$ Although the London conference ultimately decided to include the point regarding Poland in the agenda of the pending congress, the critics of the solution remained unconvinced. At the end of 1865, the articles suggesting the harmful - for the worker's cause and manipulative influence of the Polish lobby over the General Council appeared in the radical Belgian and French press (La Tribune du Peuple, Echo de Vervieres). These accusations were preposterous for Marx, P. Fox argued with them publicly, but without positive results. ${ }^{11}$ During the IWMA congress in Geneva (September 1866) the project of the General Council in relation to reinstatement of democratic and social Poland collapsed, mostly due to the French and Belgian delegates. The participants of the congress, however, were left with the possibility to voluntarily sign the pro-Polish declaration prepared by a German, Johann Philipp Becker. ${ }^{12}$ After the congress of 1866 , some members of the IWMA were still willing to engage with activities promoting the independence of Poland, although in general the organisation ceased to pay particular attention to Polish affairs.

9 Leszek Kołakowski, Gtówne nurty marksizmu (London, 1988), pp. 171-177; Ciołkosz, Karol Marks, pp. 26-28.

10 Minutes of London conferrence, 27 IX 1865, in Henryk Katz (ed),Pierwsza Międzynarodówka a sprawa polska. Dokumenty i materiaty (Warszawa, 1964), pp. 315-318.

11 Marks to Engels, 15 I 1866, in Michnik, Marks i Engels, II, pp. 28-32. Fox's polemics in The Workman's Advocate, 13 I 1866, no. 149, p. 5 .

12 Account of a discussion written by J. Ćwierczakiewicz-Card, in Katz, Pierwsza Międzynarodówka, pp. $375^{-376}$. 


\section{Polish Members of the Association}

Pierre Vésinier, who was probably the author of a text which appeared in Echo de Verviers in 1865, expressed his criticism of an excessive interest towards Poland manifested by the General Council. He wrote: "the Poles have massively asked to belong to the Committee [i.e. the General Council - ed. K.M.] and they will have a huge majority". ${ }^{13}$ How true were these statements? Were there so many Poles in the IWMA that the suggestion about their special role, or overrepresentation, was justified? The answer is - no. The Polish members were not particularly influential or numerous, although their presence in the IWMA was always visible. Since 1864, there was a position of the Corresponding Secretary for Poland within the General Council - which was held consecutively by the Poles: Jan Emil Holtorp (1864-65), Konstanty Bobczyński (1865-67), Antoni Żabicki (1867-71) and Walery Wróblewski (1871-76). Moreover, the members of the Council at different times were: Franciszek Rybczyński, Ludwik Oborski, Jan Kryński, Józef Michał Werecki, Włodzimierz Rożałowski and Józef Rozwadowski. They weren't dead souls within the organisation, and their signatures remained on many documents of the First International.

However, none of the above mentioned individuals belonged to the circle of theoretical or organisational leaders of the IWMA. The meeting minutes of the General Council point out that they were not very active during the disputes. Also, in respect to the number of ordinary members of the First International, Poland looked rather moderate in comparison with England, France, Switzerland, or Spain. Moreover, one encounters considerable difficulties in attempting a precise determination of the number of the Polish members of the IWMA. When in 1873 the new General Council in New York asked for details regarding the number of sections and their members, Friedrich Engels wrote to Friedrich A. Sorge that Walery Wróblewski (the contemporary Secretary for Poland) did not have such information, as the full secret must be kept in the activities of the IWMA on Polish territory. ${ }^{14}$ Polish historians, especially during the communist regime (1945-89), were insistently trying to recreate the Polish input in the First International, and were able to establish names of a few cities where the Association could be active. In the Russian partition this involved: Warsaw, Płock, Suwałki, Lublin, Siedlce and Łuków. In the Austrian partition the sections could exist in: Cracow, Wieliczka and Lvov. There was also a possibility that a section of the Association existed within the Prussian

\footnotetext{
13 « les Polonais ont demandé en masse à faire partie du Comité, et sous peu ils sont en immense majorité »; Quote after Katz, Pierwsza Międzynarodówka, p. 348.

14 Engels to Sorge, 20 III 1873, in Michnik, Marks i Engels, II, p. 85.
} 
partition - on the territory of Poznan. ${ }^{15}$ However, this information was based on indirect sources, and therefore cannot be considered as fully reliable. It is also impossible to determine the number of members in these Polish sections. Although the Russian agent in London, Albert Potocki (real name: Julian Aleksander Bałaszewicz), reported in 1872 to his superiors that in accordance with the information from W. Wróblewski, the three sections in Cracow comprised of around 400 members, this information cannot be verified. ${ }^{16}$

Even if the sections of the IWMA present on Polish territory were formally organised, they still remain anonymous to us. There is considerably more information about the Poles who joined the First International while in exile. The groups of political emigrants were involved in the activities of the Association in Switzerland and France. An activist of the Geneva's section of the IWMA was a representative of the Polish National Government of 1863, Józef Ćwierczakiewicz, known as Joseph Card. He was one of the co-organisers and most active participants during the Congress in Geneva in 1866, where he, as just one of very few, persistently advocated the Polish cause. The Association's members were also Walerian Mroczkowski and Jan Zagórski - who were in close relations with Mikhail Bakunin - both resided in Lausanne for some time. According to Polish historians, the Paris sections of the IWMA also involved a few Poles. ${ }^{17}$

Definitely the best documented and probably most numerous was the contribution to the IWMA's efforts made by the London branch of Polish emigration. The leaders of the Association in Britain - Karl Marx and some British trade unionists - were more sympathetic towards Poland than its continental members, where the IWMA was associated with the name and writings of P.J. Proudhon. In consequence, closer relations with the Association in England were even sought by those Polish emigrants who chose not to fully identify themselves with its programme. The Polish section of the IWMA was established in London (most likely in 1865), joined by the former members of the Polish Democratic Society (Towarzystwo Demokratyczne Polskie) and the Communes of the Polish People (Gromady Ludu Polskiego). When in 1866 they had established a new organisation, called London Commune of the

\footnotetext{
15 Jerzy Borejsza, W kręgu wielkich wygnańców (1848-1895), (Warszawa, 1963), pp. 76-77, 97-101; Ryszard Kołodziejczyk (ed), Historia polskiego ruchu robotniczego (Warszawa, 1985), I, p. 205.

16 Julian Bałaszewicz's report, London 12 I 1872, in Albert Potocki (Julian Aleksander Bałaszewicz), Raporty szpiega, ed. Rafał Gerber, (Warszawa, 1973), II, pp. 279-280.

17 Jerzy Borejsza, Emigracja polska po powstaniu styczniowym, (Warszawa, 1966), pp. 361-367; Kołodziejczyk, Historia polskiego, pp. 200-203.
} 
Polish Emigration Union (Gmina Londyńska Zjednoczenia Emigracji Polskiej), it became part of the IWMA. The membership fees paid by the Polish section for the years 1866 and 1867 may suggest that this section numbered around 60 people, from which several surnames are known. ${ }^{18}$ With time this group had undergone a certain dispersion, as some emigrants returned to Polish territories (mostly to Galicia, remaining in the hands of the Austrians ${ }^{19}$ ). The next revival of the Polish activity within the First International came along with the fall of the Paris Commune and the influx of a dozen or so of its Polish participants to London. They had become the force behind the reactivated Polish section of the IWMA in London, between 1871 and 1872 . This section numbered around 40 to 50 members, who later established a new Polish organisation, the Union of the Polish People (Związek Ludu Polskiego). Both the Polish section in the First International and the Union of the Polish People ceased their activities in $1876 .^{20}$

Who were the Polish members of the First International? Our knowledge about the people who joined of the Association in Poland is very sparse and limited to the fact that they mainly came from a working-class background. ${ }^{21}$ Those who lived in exile comprised of the different waves of participants in the struggle for the Polish independence, who emigrated after unsuccessful uprisings. Among them were the veterans of the November Uprising, who fought against Russia in 1830-31, like Colonel Ludwik Oborski (1789-1873), a well-known veteran who gained his experience during Napoleonic campaigns, serving in the Polish units under the French command. He joined the army of the Kingdom of Poland, and subsequently participated in the Rising of 1830. After its collapse he emigrated to France, and then stayed for a while in Switzerland, the United States, and finally in England. Oborski was engaged in the radical Polish politics in exile, and was also associated with the Fraternal Democrats. Between 1848 and 1849 he took part in the revolutionary struggle on the territory of Poznań and in Baden, and afterwards returned to England. Ludwik Oborski was considered to be a soldier rather than a politician or theoretician but he consequently was associated with the left-wing of the

18 Register of fees paid by British sections of IWMA for the years 1866/67, in Katz, Pierwsza Międzynarodówka, pp. 423-424.

19 Among them was the second Secretary for Poland, Konstanty Bobczyński. After returning, he engaged in local politics, and in the 188 os became a member of the Galician provincial parliament; see Feliks Tych (ed), Stownik biograficzny dziataczy polskiego ruchu robotniczego (Warszawa, 1978), I, p. 244.

Borejsza, Emigracja polska, pp. 369-376, 405-410; Koberdowa, Pierwsza Międzynarodówka i lewica, pp. 114-122, 264-281.

21 Julian Bałaszewicz's report, London 18 I 1872, in Potocki, Raporty szpiega, II, pp. 280-281. 
Polish political scene. ${ }^{22}$ Another Polish member of the General Council of the IWMA, Jan Kryński (1811-90), was also a veteran of the 1830 November Uprising. He joined the uprising while still a student of the University of Warsaw and during the fight he was promoted to the rank of Lieutenant. After the Rising he left the country, worked in London as a shoemaker, and was an active member of the most radical Polish organisation in exile, the Communes of the Polish People. Similarly to Oborski, he collaborated with the International Association in the 1850 os before he joined the IWMA. ${ }^{23}$

The revolutions of 1848-49 provided the next generation of Polish freedomfighters who joined the IWMA. Two successive Secretaries of the IWMA for Poland were Konstanty Bobczyński (1817-93) and Antoni Żabicki (1818-89). They were engaged in the independence struggle and conspiracy in the Austrian partition in the 1840 . Bobczyński was arrested by the Austrians while Żabicki managed to emigrate. They took part in the Hungarian uprising of 1848-49, both as officers. After the Hungarians surrendered, they fled to Britain through Turkish territory. Both were active in the largest political organisation of the Great Emigration (Wielka Emigracja) - the Polish Democratic Society (TDP), which after 1849 had moved its centre from France to England. Żabicki mainly concentrated on publishing and writing, and in $185^{2}$ he had become a member of the top-level management in the party, the so-called Centralizacja TDP. In 1863, Bobczyński took part in the unsuccessful mission of the ship "Ward Jackson", the goal of which was to deliver arms to the Polish insurgents in Lithuania. ${ }^{24}$

The third generation of Polish activists, who were associated with the IWMA, included the emigrants who left Poland after the January Uprising (1863-64). General Walery Wróblewski (1836-1908) was especially visible in this group. During the battles with the Russians, which he carried out until 1864, he was in command of several guerrilla units. Wróblewski emigrated to France where he joined the Garde Nationale in 1870, defending Paris against the Prussians. He also participated in the 1871 Paris Commune, commanding the forces on the left bank of the River Seine. Following the collapse of the Commune, he escaped through Belgium to Britain. ${ }^{25}$ Except Wróblewski, there were a few more Polish communards and the insurgents of 1863 who entered the First International. Among them was Włodzimierz Rożałowski $\left({ }_{1838-76)}\right.$ who joined the January

22 Bogusław Cygler, PutkownikLudwikOborski-szermierz wolności (1789-1873) (Gdańsk, 1976).

23 Polski Stownik Biograficzny (Wrocław, 1970), xv, pp. 467-468.

24 Borejsza, $W$ kręgu wielkich, pp. 472-473; Marian Tyrowicz, Towarzystwo Demokratyczne Polskie 1832-1863. Przywódcy i kadry członkowskie (Warszawa, 1964), pp. 45-46, 824-825.

25 Jerzy Borejsza, Patriota bez paszportu, (Warszawa, 1970). 
Uprising by leaving the Russian army. He was interned in Austria for nearly three years and after his release he travelled to France. Rożałowski fought at the Franco-Prussian War, and during the Paris Commune was a member of the staff of General Jarosław Dąbrowski. Another participant of the Paris Commune was Józef Rozwadowski (1846-1878). Although his role in the January Uprising is not known, for some reason he left Poland in the 186os. Before the Franco-German War, he studied in the Artillery School in Metz, and in 1870 he fought against the Prussians under the command of François de Rochebrune. The Paris Commune promoted him to the rank of Colonel and entrusted him with the defence of the XIII arrondissement. Similarly to Wróblewski and Rożałowski, Rozwadowski managed to escape and travelled to London, where he joined the General Council of the IWMA. ${ }^{26}$

\section{For Homeland or for Social Justice?}

It seems interesting, or even paradoxical, that all seven above-mentioned men had come from Polish gentry (szlachta). The same applies to many Polish members of the First International, e.g. Józef Ćwierczakiewicz (Card), Jan Kanty Kostecki, Mikołaj Koziełł-Poklewski, or Teofil Dąbrowski (a brother to General Jarosław Dąbrowski). They weren't high aristocrats, but rather sons of the impoverished noble families. In the nineteenth century this social stratum had partially transformed into the Polish intelligentsia, which undertook professional activity characteristic for the middle class. Many of them mingled into the working class, what was often the case of the emigrants in Western Europe. However, it was not the noble background that constituted the common denominator for all Polish members of the IWMA in England, France or Switzerland. What all of them had in common was their involvement in the Polish independence movement. Therefore, it is important here to focus on the real motives which determined their access to the Association. Was it a priority for the Poles, who joined the First International, to improve the condition of the working class, or rather this was just another platform to struggle for the freedom of Poland?

There is no straightforward and simple answer to this question. As Felicja Romaniukowa wrote, in the nineteenth century, "it was characteristic for the Polish revolutionists in exile that they joined every institution, association or union, if there was even the slightest chance to voice publicly the right to

26 Borejsza, W kreggu wielkich, pp. 483-484, 498-499; Polski Stownik Biograficzny (Wrocław, 1989/1991), XXXII, pp. 413-414, 429-431. 
regain independence, once brutally taken". ${ }^{27}$ Without a doubt, the political views of many Poles who belonged to the IWMA were distant from the social concepts of Marx or Proudhon. The first Polish members of the Central Council, J.E. Holtorp and F. Rybczyński, did not hide their fascination for Giuseppe Mazzini's republican thought, and they distanced themselves from the First International relatively soon. Some others, who declared themselves as democrats, appeared to have serious objections to be even called socialists. A Polish periodic published in London, Gtos Wolny, observed in 1869: "[In Poland] The national and political problems overshadow all the matters, this absorbs all the attention of the present generation ... A Pole, who presents himself as a socialist seems to us as at least ridiculous, or just as temporarily overwhelmed by the ideas far from a patriotic duty". ${ }^{28}$ It may be interesting to note that the editor of Gtos Wolny at the time was the Polish Secretary of the IWMA Antoni Żabicki, and the journal attracted many members of the Polish section of the Association. The Poles who chaired the General Council rather occasionally voiced their opinions during big theoretical disputes. It is not unreasonable to believe that they were in favour of Marxists and against the Proudhonians mostly because of the differences in their opinions concerning the Polish cause. Taking into consideration reluctance towards radical socialist programmes presented by some emigrants returning to the country, will produce a picture of the Polish section (or at least its part) as a somewhat "alienated" within the IWMA, and concentrated around the possible support of this organisation for exclusively Polish interests.

On the other hand, it should be remembered that among the Polish members of the Association were also representatives of the Communes of the Polish People (e.g. J. Kryński or L. Oborski), whose since 1830 s had articulated the need for social revolution, popularised common ownership of land, demanded nationalization of factories, workshops and banks, and projected systems of social security. ${ }^{29}$ Although on account of the Polish economic realities, the Communes focused on problems of peasants and agricultural labourers rather than the industrial proletariat, they were committed socialists for whom the First International was a natural political environment. Moreover, since 1850 a gradual radicalisation of the entire Polish exile can be observed. The influence of the conservatives became limited, and more and more former

27 Felicja Romaniukowa, "W sprawie udziału Polaków w I Międzynarodówce”, Kwartalnik Historyczny, 68/2, (1961), no. 2, p. 333.

28 Gtos Wolny, 15 XII 1869, no. 215/216, p. 864, quote after Borejsza, Emigracja polska, pp. $35^{6-357 .}$

29 See Hanna Temkinowa (ed), Lud Polski. Wybór dokumentów (Warszawa, 1957). 
representatives of the moderate center began to express socialdemocratic and republican views. ${ }^{30}$ This radicalisation was also visible in a short history of the Polish section of the IWMA. Reestablished in London after 1871, the new section had a much deeper social and ideological consciousness than its predecessor. It encompassed not only the members of the Paris Commune, but also many others well aware of the fact that the reconstruction of Poland required gaining over to this cause the Polish workers and constant cooperation with them. Thus, W. Wróblewski and J. Rozwadowski had remained under the strong influence of Marx, popularised his Communist Manifesto in Poland, and they combined national projects with social matters. ${ }^{31}$

In the second half of the twentieth century, the Polish section of the First International became a subject of considerable interest on the part of Polish researchers. The communists ruling in Warsaw in the years $1945^{-89}$ perceived the activists of the First International as their political predecessors, and their relations with Karl Marx and Friedrich Engels became the important element in the founding myth of the twentieth century communist parties in Poland. The political tension surrounding this subject resulted in the disproportionally great importance attached to the Polish chapter in history of the IWMA. It was during this period, when the majority of the Polish studies concerning the First International had been written. Wróblewski, Oborski, and others, were presented as outstanding political leaders and visionaries who in the best possible way predicted the future of Europe and Poland. They have streets named after them and even history textbooks in elementary schools mentioned their names.

Now, while they have sunk into relative oblivion, it is easier to give a more balanced opinion on their historical role. It is true that the individuals who were affiliated with the First International constituted at that time the most radical group of the Polish left-wing. Their programme of reconstruction and then socialist rebuilding of the Polish state and society was clearly different from the proposals presented by other Polish national factions. In this sense, the Polish members of the IWMA were the precursors of the later socialist and communist parties in Poland (although many of them certainly would

\footnotetext{
30 Sławomir Kalembka, Wielka Emigracja 1831-1863 (Toruń, 2003), pp. 323-338, 358-362.

31 The first Polish translation of Communist Manifesto appeared in 1848. It was followed by next editions in 1883 and 1892 . Other texts by Marx and information about the activities of the IWMA were published by the Polish emigrational periodicals as Gtos Wolny; Niepodlegtość; Prawda; Nowiny z Wychodźstwa i Kraju since the 186os. They were distributed not only amongst the Poles abroad but also - illegally - in Poland. Cf. Borejsza, Emigracja polska, pp. 373-381, 402-410; Koberdowa, Pierwsza Międzynarodówka i lewica, pp. 138-140.
} 
not be enthusiastic about brutal methods used to implement communism in the country after 1945). On the other hand, it wouldn't be appropriate to consider many Polish members of the Association as Marxists. For some of them the main goal was simply an independent and democratic Poland. On entering the IWMA, they treated it similarly to the organisations operating in the 1840 s and 185os, such as the Fraternal Democrats, the Central Committee of the European Democracy or the International Association. They perceived all of these bodies as potential allies in the struggle for freedom and the rights of small nations to self-determination. The First International was relatively less interested and active in these matters than the previously mentioned organisations; therefore, the Poles had fewer opportunities to voice their opinion within it. That is mostly why, although they were visible as a group, they held such a secondary role within the IWMA. 